\title{
Branchipus blanchardi Daday 1908 in the Alps : redescription from type locality and synonymy with $B$. alpinus Colosi 1922 (Crustacea, Anostraca)
}

\author{
M. Alonsol \\ Keywords : Branchipus blanchardi, B. alpinus, Anostraca, France. \\ Branchipus blanchardi Daday 1908 is redescribed from the type locality, a small temporary pond near Cristol lake (Hautes- \\ Alpes, France). The redescription shows that the male of this species is characterized by two bilobated outgrowths on \\ the anterior side of clypeus, the distal segments of antenna 2 broadly enlarged in the middle and two conical outgrowths \\ on the II to VII abdominal segments. This last characteristic does not agree with Daday's original description in which \\ four outgrowths figured and allows us to establish the synonymy between $B$. blanchardi and $B$. alpinus Colosi 1922 .
}

Branchipus blanchardi Daday 1908 dans les Alpes : redescription à partir de la localité type et synonymie avec B. alpinus Colosi 1922 (Cnistacea, Anostraca).

Mots clés : Branchipus blanchardi, B. alpinus, Anostraca, France.

Branchipus blanchardi Daday 1908 est redécrit à partir d'échantillons récoltés dans la localité type, une petite mare temporelle près du lac Cristol (Hautes-Alpes, France). La redescription montre que le mâle de cet te espèce est caractérisé par deux processus bilobulés à la part antérieure du clypeus, par les segments distaux de la deuxième antenne beaucoup plus élargis à la moitié, et par deux excroissances coniques aux segments abdominaux II à VII. Ce dernier caractère n'est pas en accord avec la description originale de Daday dans laquelle sont figurées quatre excroissances et nous permet d'établir la synonymie entre B. blanchardi et B. alpinus Colosi 1922.

\section{Introduction}

Branchipus blanchardi Daday 1908 was described from specimens collected in a pond close to Cristol lake (Hautes-Alpes) by R. Blanchard in September 1888. The most outstanding characteristics in defining the species were the expanded second antenna and four outgrowths on each abdominal segment. After the description only additional information of this species can be found in Daday (1910) and in Nourisson \& Thiéry (1988). Type material (two males and one female) is deposited in the Museum d'Histoire Naturelle, Paris, but unfortunately it is nowadays aimost distroyed and useless for taxonomical studies (Thiéry in litt).

\footnotetext{
1. Departanent d'Ecologia, Facultat de Biologia, Universitat de Barcelona, Avda. Diagonal 645, 08028 Barcelona (Spain).
}

The purpose of this paper is to redescribe $B$. blan. chardi from type locality in order to give more details about the morphology of this species and to make further taxonomical analysis within the genus easier. The redescription shows some differences with Daday's description, the most important concerns with the morphology of abdominal segments since the neotype has only two outgrowths instead four. This difference was hitherto used to separate Branchipus alpinus Colosi 1922 from B. blanchardi therefore both species must be considered as identical.

\section{Materials and methods}

Samples were taken with a $100 \mu \mathrm{m}$ mesh sampling net and fixed with $4 \%$ formaline. Material examined: 120 males and 20 females collected in two 
ponds near Cristol lake, Hautes-Alpes at $2000 \mathrm{~m}$ a.s.1. in 6 August 1987 ; one of the ponds was located in the shoreline of the lake and the other $300 \mathrm{~m}$ far from it. The sample of the first pond had only males whereas both mature males and females were collected in the second pond. Camera lucida drawings were made with a Olympus $\mathrm{BH} \cdot 2$ compound microscope provided with phase-contrast optics. Terminology follows Linder (1941) and Fryer (1983).

\section{Results}

Branchipus blanchardi Daday 1908 (Emend. Alonso)

\section{SYNONYMY}

Branchipus blanchardi Daday 1908, Daday 1910, Nourisson \& Tiery 1988. B. alpinus Colosi 1922, Cottarelli 1968, Cottarelli \& Mura 1983.

\section{NeOTYPE}

A mature male $11,7 \mathrm{~mm}$ in length preserved in $4 \%$ formaline with glycerol has been deposited in the Department of Ecology of Barcelona University, Catalog number E.M.A. H.008, This specimen agrees completely with the description given in this work.

\section{TYPE LOCALITY}

Very close to that of the first description. A pond $300 \mathrm{~m}$ east from Cristol lake, Nevache, Hauts Alpes (France). It is a temporary water body frequented by sheep, with a surface of about $150 \mathrm{~m}^{2}$ and $40 \mathrm{~cm}$ maximum deep. Water was clean, very low mineralized and macrophytic vegetation scarce.

\section{Paratypes}

20 females and 120 males preserved in $90 \%$ ethanol have been deposited in the collection of the Department of $\mathbf{E}$ co logy, Barcelona University, Catalog number E.M.A. P.008.

\section{Description}

\section{FeMALE}

Length to end of cercopods $9.5-11,5 \mathrm{~mm}$ (According to Daday (1910), maximum length can reach $18 \mathrm{~mm}$ ). Ratio of head and thorax length to abdomen and cercopods length about $1: 1$. No pigmented body.

Head (Fig. 1, a, b). Nuchal organ elliptic. Antenna 1 biarticulate with three long sub-terminal setae and eigth aesthetascs. Antenna 2 conical with sharp end ; two tufts of sensory setae, one proximal and the other subdistal. Labrum (Fig. 1, c) ends in a small lamella and has no apical protuberances (Fig. 1 a); spinous pad (SP) acute. Maxilla 1 provided with 18-20 setae and a small posterior ventral spine (Fig. 1 d). Maxilla 2 (Fig. $1 \mathrm{f}$ ) has swollen proximal part provided with two soft setae; finger-like distal part with a long plumose seta at tip. Two groups of six small setae at the beginning of oesophagus (Fig. $1 \mathrm{~g}, 1 \mathrm{~h}$ ).

Thoracic limbs. Ten first thoracic limbs (Fig. 2 a) with one single praeepipodite with no deeply serrated margin and an incision in half the height. Epipodite with smooth margin. Exopodite elongated with five proximal spine-like setae on outer margin. Endopodite sub-quadrangular with two - four proximal short spine-like setae on inner margin (Fig. 2 c, 2 l). Pectinate scales with 3-10 small tooth in base of setae (Fig. 2 a'). Endites 3, 4 and 5 with 2, 2, 1 (first limb may have 2,2,2) anterior short setae and 3, 2, 2, long posterior setae (Fig. 2 c, 2 l). Anterior spine of proximal part of endite 2 is almost twice anterior spine of endite 1 , both two have a small roughly chitinized denticle at he base (Fig. 2 a"). There are about 9 setae each $100 \mu \mathrm{m}$ in middle part of filtering comb of endite 1 .

Last (eleventh) thoracic limb (Fig. 2 b, 2 m). with margin of praeepipodite only serrated on distal part ; medial incision present. Epipodite with margin serrated at tip. Endites 2, 3,4 and 5 of about same size and globular. Anterior spine of endite 2 very small with a small denticle close to its base. Anterior spine of endite 1 substituted by a small denticle. Ovisac (Fig. 1 l, 1 ..1) short and not expanded laterally; short ventral elongation extends until middle of thirth abdominal segment ; ventral anterior lobe as high as abdominal segment with posterior side heavily pigmented; $6-8$ resting eggs (Fig. $1 \mathrm{n}, 1 \mathrm{p}$ ) of irregular outline with several polygonal crests ; approximate diameter $0.35 \mathrm{~mm}$.

Abdominal segments smooth (Fig. 1 i, 1 k). Ventral sensory setae on segments 4,6 and 8 ; lateral sensory setae on segments $3,5,7$ and 8 ; dorsal sensory setae only on segment 8 .

Cercopods (Fig. 1 i) as long as three last abdominal segments plus telson provided with long setae on both inner and outer sides.

\section{MALE}

Length to end of cercopods $9.7-12 \mathrm{~mm}$ (specimens from smal pool in the shoreline of Cristol lake were 13- $14.2 \mathrm{~mm}$ and according to Daday, 1910, maximum length is $17 \mathrm{~mm}$ ). No pigmented body. 

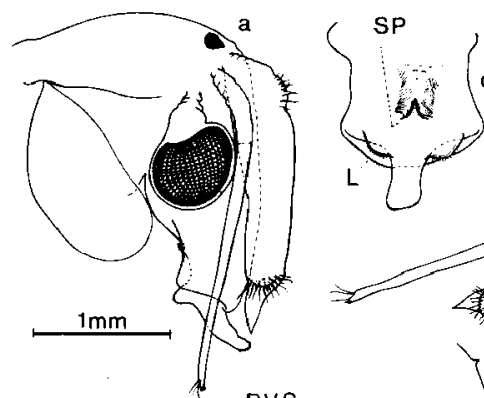

b
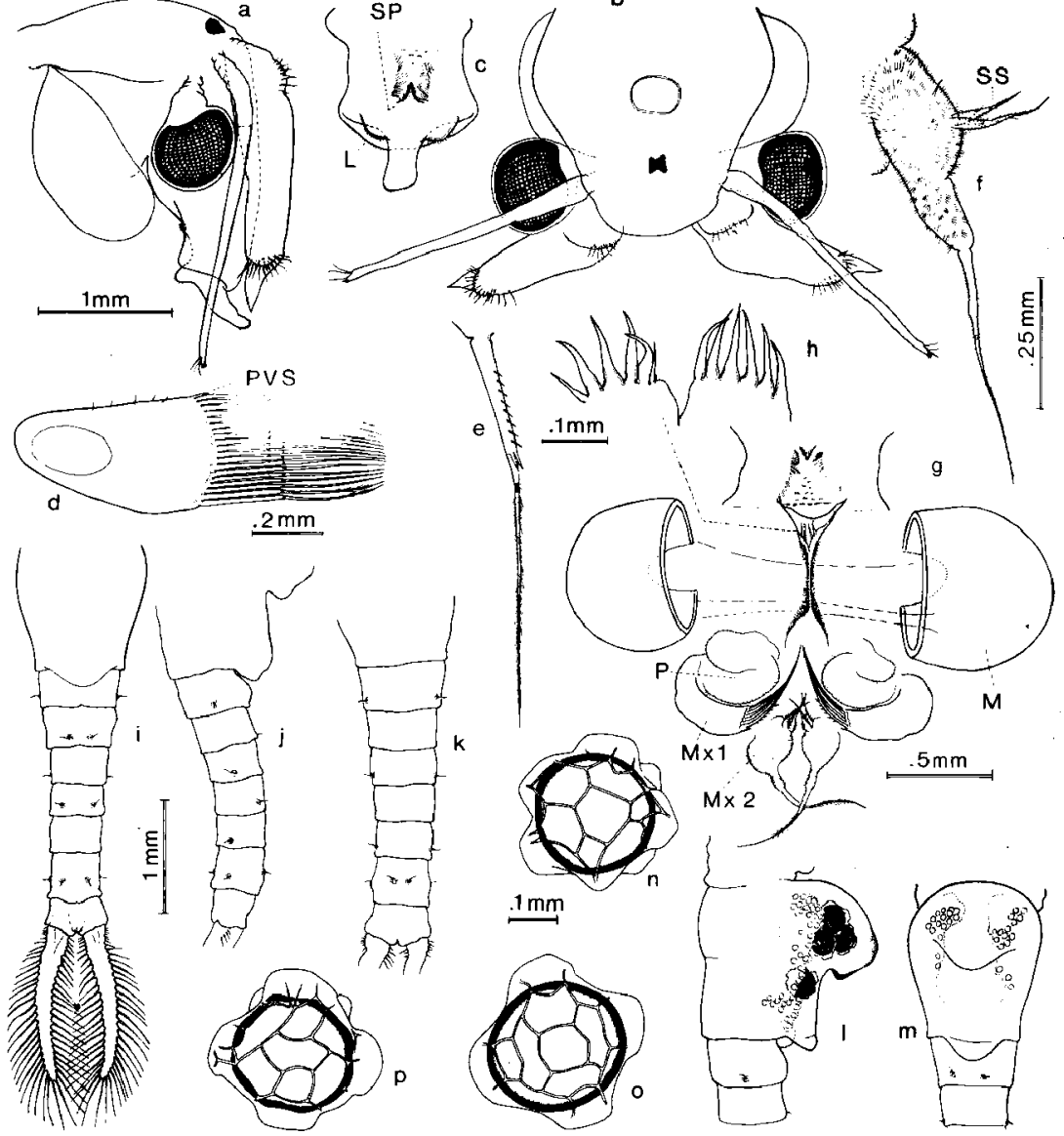

Fig. 1 : Branchipus blanchardi Daday from Cristol lake (Hautes Alpes). Female : a, lateral view of head ; b, dorsal view of head : $c$, ventral view of labrum ; d, maxilia 1 (PVS = posterior vent ral spine) ; e, detail of seta of maxilla 1 ; $f$, maxilla $2(\mathrm{SS}=$ soft setae $) ; \mathrm{g}$, mouth appendages $(\mathrm{M}=$ mandible $; \mathrm{P}=$ paragnath $; \mathrm{Mx} 1=\operatorname{maxilla} 1 ; \mathbf{M x 2}=\operatorname{maxilla} 2) ; \mathrm{h}$, setae of beginning of oesophagus; $i$, ventral view of abdomen, telson and cercopods; $j$, lateral view of abdomen; $k$, dorsal view of abdomen; 1 , lateral view of ovisac ; $m$, ventral view of ovisac; $n$-p, resting eggs. 
Antenna 2 (Fig. 3 a, $3 \mathrm{~g}$ ). Basal segments of antenna 2 are completely joined medianly forming the clypeus as is normal in the family Branchipodidae. Anterior quitinous outgrowths of clypeus well developed with two lobes, dorsal one longer than ventral one ; from dorsal view, dorsal lobe appears closer to midline of body than ventral lobe ; tip of both lobes exceed distal end of clypeus. Two dorsal soft setulated outgrowths in each side of clypeus ; proximal ones near the base of frontal appendages barely protruding; distal ones more elongated \& turkeycrest "-shaped. Frontal appendages consisting in two whip-shaped formations arising from dorsal proximal portion of clypeus as is characteristic in the genus ; proximal portion broad and compressed with " 8 "shaped section; distal portion with rounded section ; tip roughly exceeds antenna 2 in length and appears curved ventralward. Distal segments almost as long as clypeus; they appear curved inward from dorsal and ventral view and " $S$ " shaped from lateral view; medial part strongly enlarged as is shown in Fig. $3 \mathrm{~d}$ and in the cross-section (Fig. $3 \mathrm{~g}$ ) : distal end with two tips, ventral one longer and sharper than dorsal one.

Antenna 1 as in female (Fig. $2 \mathrm{~g}$ ).

Thoracic limbs. General structure as in female. Endites 4 and 5 of first thoracic limb (Fig. 2n, 2 n') provided with three anterior setae instead of two as in the female (occasionally there are also only two in males).

Genital organs. Genital segments higher than the other segments (Fig. 3 i) but not significantly broader. Vesicula seminalis not differentiated from vas deferens (Fig. 2 o). Basal part of penis joined with a medio-ventral pore-like structure whose significance remains still unclear (Fig. 2 o). In inner side of basal part of penis a curved spine-like outgrowths is developed. Retractile part of penis clearly differentiate from basal part and somewhat longer, provided with two dorsal longitudinal rows of small spines; doubling spines appear toward tip (Fig. 2 p).

Abdominal segments (Fig. $3 \mathrm{~h}, 3 \mathrm{k}$ ). Two ventrallateral cuticular outgrowths on both sides of posterior rim of second to seventh segments; whose of second segment are very small. Sensory setae distribution as in fernale.

Cercopods as long as four last abdominal segments plus telson, strongly curved inward; inner and distal lateral setae very reduced in length (Fig. 3 h).

\section{Geographical distribution and ecology}

The distribution of Branchipus branchardi us up to now restricted to the Alps over $1800 \mathrm{~m}$ a.s.I. It colonizes small temporary mountain water bodies, sometimes isolated but also related with bigger permanent lakes. The water is clean but scarcely colonized by aquatic vegetation; sediment is clayey. Accompanying crustacean species are Arctodiaptomus bacillifer, Chydorus sphaericus s. lat., Daphnia longispina and Moina brachiata. The three former species are very common in the mountain waters of the Alps (Tonolli \& Tonolli 1951), however $M$. brachiata seems more characteristic of steppic aquatic environments (Alonso 1985).

\section{Discussion}

Compared with the rest of the known Branchipus, $B$. blanchardi is probabily the most distinct species. The most outstanding characteristics in separating it from the rest of the species of the genus are the following :

1) The anterior outgrowths of the clypeus have two prominent lobes in B. blanchardi whereas there is only a lobe in the other species (B. schaefferi Fisher 1934 ; B. laevicomis Daday 1912, B. pasai Cottarelli 1969, Branchipus visnyai Kertész 1956).

2) Distal segments of antenna 2 provided with large flat lateral expansions in the middle.

3) Two ventral-lateral conical cuticular outgrowths on the second to seventh male abdominal segments. Such structures are common among the order Anostraca but are unique among the species belonging the genus Branchipus (In Daday's original description there are four outgrowths in each segment).

4) Two-four proximal short spine-like setae on inner margin of endopodite.

The description of $B$. blanchardi given in the present paper differs from that of Daday (1910) in the structure of the male abdominal segments; in my opinion it is within the bounds of possibility that Daday's description of this character was incorrect. On the other hand, if we accept that $B$. blanchardi has two conical outgrowths on the abdominal segments instead four as figures by Daday, B. blanchardi from Cristol lake and B. alpinus Colosi 1922 


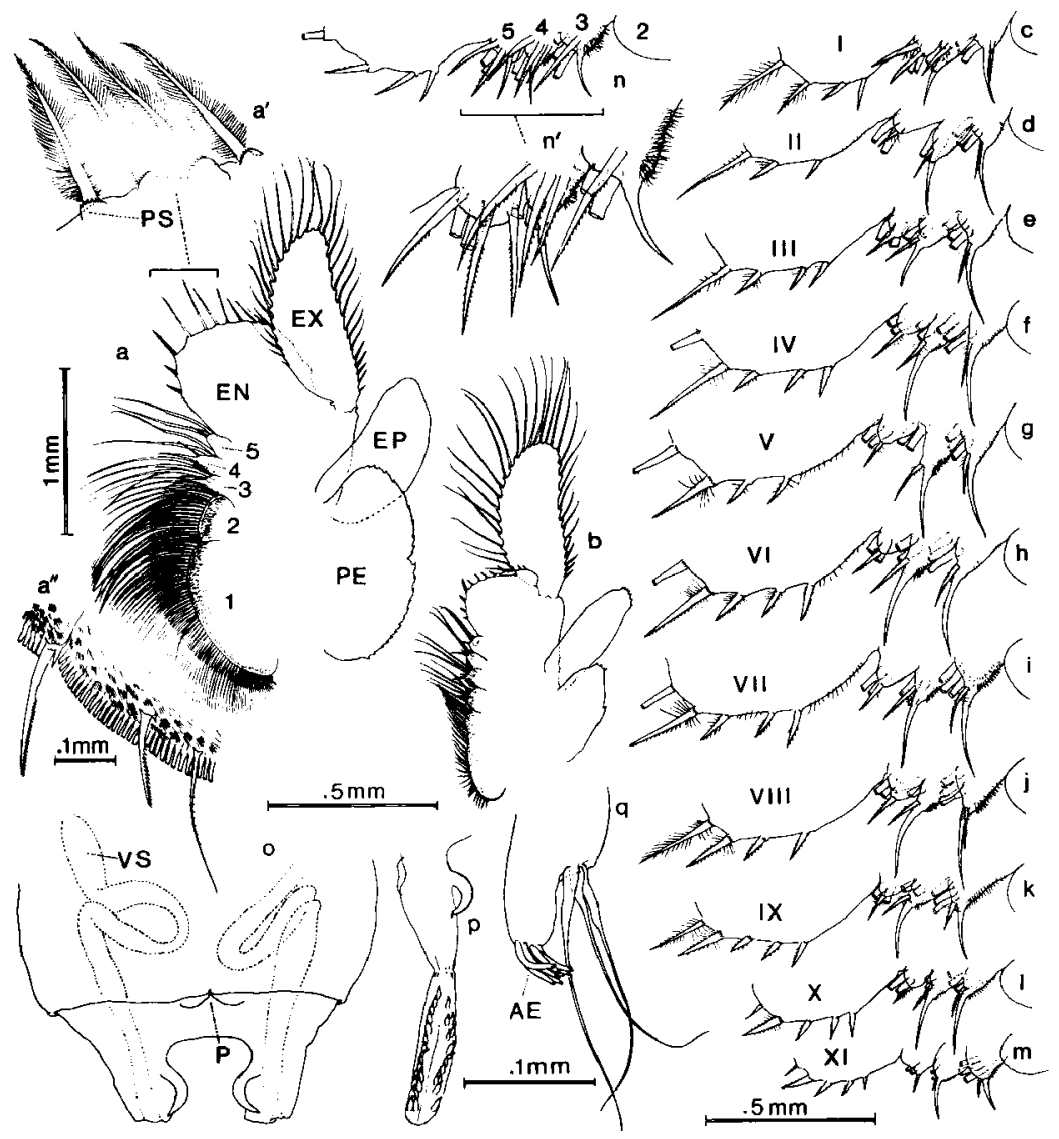

Fig. 2 : Branchipus blanchardi Daday from Cristol lake (Hautes Alpes). Female : a, fifth thoracic limb (numbers correspond to different endites $; \mathrm{EN}=$ endopodite $; \mathbf{E X}=$ exopodite $; \mathbf{E P}=$ epipodite $; \mathbf{P E}=$ praeepipodite); $\mathbf{a}^{\prime}$, detail of setae of distal part of endopodite (PS = pectinate scales) ; $a^{\prime \prime}$, detail of anterior spines of endite 1 and 2 ; $b$, eleventh thoracic limb; c-m, endites 3,4 and 5 , and spine-like setae of the proximal part of endopodite of thoracic limbs I to $X I$. Male : $o$, genital segment showing basal part of penis $(P=$ pore-like structure : VS $=$ vesiculae seminales $) ; p, b a s a l$ and retractile parts of penis; $q$, distal end of antenna 1 ( $A E=$ aesthetascs). 


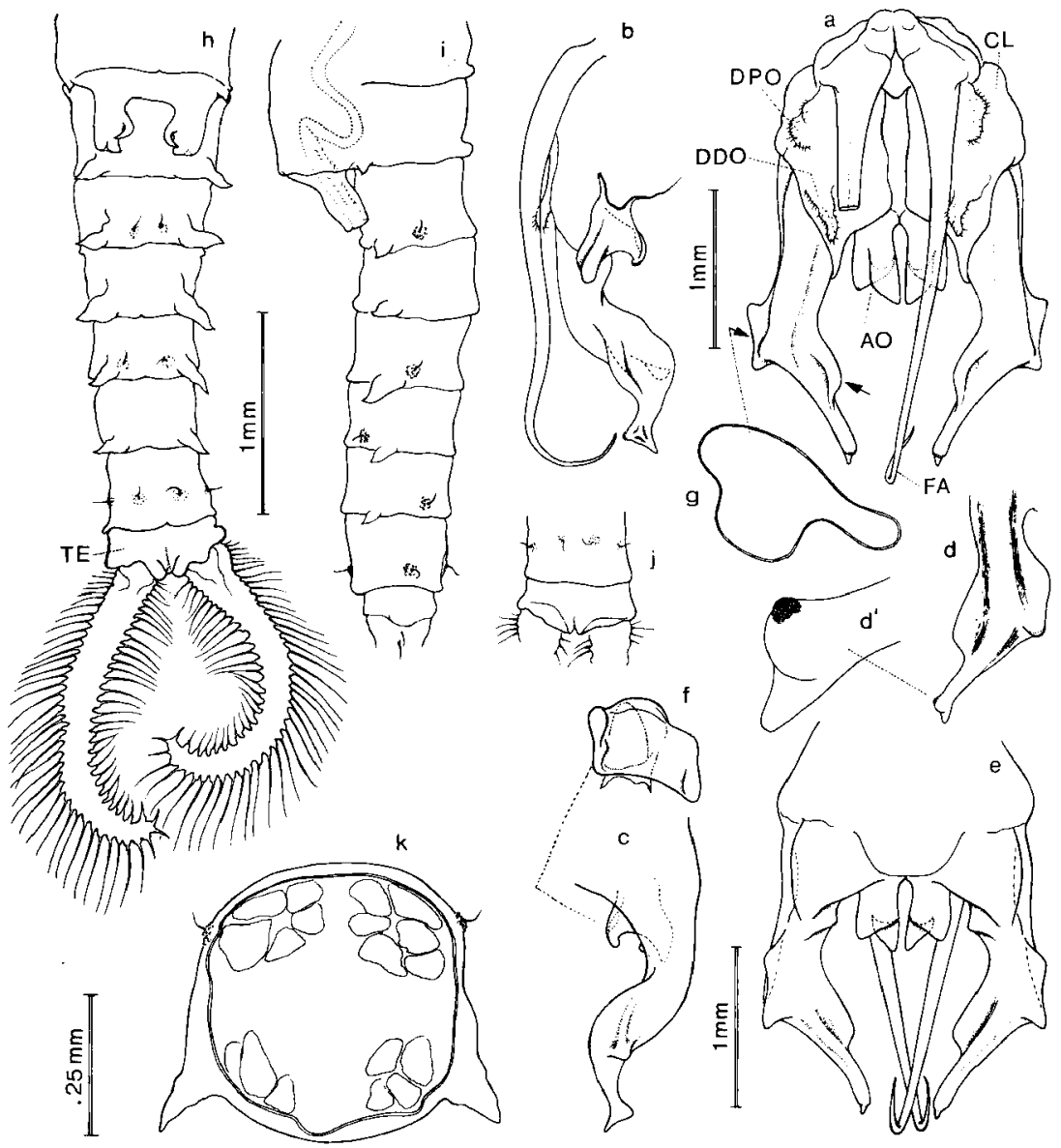

Fig. 3: Branchipus blanchardi Daday from Cristol lake (Hautes Alpes). Male : a, dorsal view of antennae 2 (CL $=$ clypeus, $\mathrm{DPO}=$ dorsal proximal outgrowth, $\mathrm{DDO}=$ dorsal distal outgrowth. $\mathrm{AO}=$ anterior outgrowth, FA, frontal appendage) $;$ b, lateral view of inner side of right antenna 2 ; $c$, lateral view of outer side of right antenna 2 ; d, detail of dorsallateral view of second segment of left antenna 2 ; d', detail of distal end of antenna 2 ; e, ventral view of antennae 2 : frontal view of right anterior outgrowth of clypeus ; $g$, cross-section of enlarged part of second segment of right antenna $2 ; \mathrm{h}$, ventral view of abdominal segments, telson (TE) and cercopods ; $i$, lateral view of abdominal segments and telson $: \mathrm{j}$, dorsal view of last abdominal segment and telson; $\mathbf{k}$, cross-section of seventh abdominal segment. 
from Piemonte (Italy) redescribed by Cottarelli (1968) have to be considered synonymous. Both taxa share the most significative morphological features in defining B. blanchardi, their localities are very close in the Alps $(75 \mathrm{~km}$ in a straight line between two localities) and their autoecology is very similar. Minor differences found between Cristol and Piemonte populations such as the number of abdominal segments with outgrowths (They are absent in seventh segment in the population of Piemonte) could be interpreted as intraspecific variability.

\section{References}

Alonso (M.). 1987. - Las lagunas de la España peninsular: Taxonomia, ecologia y distribución de los cladóceros. Col. lecció Tesis Doctorals Microfitxades 139, Universitat de Barcelona. $795 \mathrm{pp}$.
Cottarelli (V.). 1968. - Su Branchipus alpinus Colosi (Euphyllo poda, Anostraca). Archivio Zoologico Italiano, 53: 353-365.

Daday de Deés (E.). 1910 - Monographie Systematique des Phyllopodes Anostracés. Annls. Sci. nat. Zool., 9. ser., 9 : 91489.

Fryer (G.). 1983. - Functional ontogenetic changes in Branchinecta ferox (Milne-Edwards) (Crustacea : Anostraca). Phil. Trans. $R$. Soc. Lond. B. 303 : 229-343.

Linder (F.). 1941. - Contributions to the morphology and the taxonomy of the Branchiopoda Anostraca. Zool. Birdr. Uppsala, 20: 101-302.

Nourisson (M.) \& Thiéry (A.). 1988. - Crustacés Branchiopodes in Introduction pratique à la systématique des organismes des eaux continentales françaises. Bull, mens. Soc. linn. Lyon, 57 fasc. 3, $53 \mathrm{pp}$

Tonolli (V.) \& Tonolli (L.). 1951. - Osservacioni sulla biologia et ecologia di 170 popolament zooplantonici di laghi italiani di al ta quota. Mem. Ist. Ital. Idrobiol., 6 ; 53-136. 